\title{
Geopatrimônio de Prudentópolis (PR) e seu potencial para o desenvolvimento do geoturismo
}

\author{
Prudentópolis geoheritage (Paraná, Brazil) and its potential for \\ the development of geotourism
}

\section{Geopatrimónio de Prudentópolis (Paraná, Brasil) y su potencial para el desarrollo del geoturismo}

\author{
Carlos Alexandre Rogoski \\ https:/ / orcid.org/0000-0001-5732-256X \\ carlos-alexandre941@hotmail.com \\ Universidade Estadual de Ponta Grossa, UEPG, Ponta Grossa, PR \\ Antonio Liccardo \\ https:/ / orcid.org/0000-0001-7981-9630 \\ aliccardo@uepg.br \\ Universidade Estadual de Ponta Grossa, UEPG, Ponta Grossa, PR
}

Resumo: Prudentópolis, localizada na mesorregião sudeste do estado do Paraná, possui uma rica geodiversidade, abordada neste artigo em 19 geossítios com relevante potencial para o desenvolvimento do geoturismo local. O levantamento e diagnóstico do geopatrimônio de Prudentópolis expuseram como principais fatores que favorecem a prática do geoturismo: 1) produção de mapa dos geossítios de relevância científica, didática e cultural; 2) visitação já existente em grande parte dos locais de interesse com infraestrutura instalada; 3) forte interação das comunidades locais com o patrimônio natural e; 4) facilidade de acesso aos geossítios.

Palavras chave: Geodiversidade, geoconservação, patrimônio geológico.

Abstract: Prudentópolis, located in the southeastern region of the state of Paraná, has a rich geodiversity, addressed in this article in19 geosites with relevant potential for the development of local geotourism. The survey and diagnostic about the geoheritage of Prudentópolis have placed as main factors that could favor the practice of geotourism: i) production of a map of geosites of scientific, didactic and cultural relevance; ii) visitation already exists in most places of interest, with infrastructure; iii) strength interaction between local communities and natural heritage, and; iv) easy access to geosites.

Keywords: Geodiversity, geoconservation, geological heritage.

Resumen: Prudentópolis, ubicada en la mesoregión sureste de del estado de Paraná, cuenta con una rica geodiversidad, abordada en este artículo en 19 geositios con potencial relevante para el desarrollo del geoturismo local. La encuesta y el diagnóstico del geopatrimónio de Prudentópolis han colocado como principales factores que 
favorecen la práctica del geoturismo: 1) producción de mapa de geositios de relevancia científica, didáctica y cultural; 2) visitación ya existente en la mayoría de los lugares de interés, con infraestructura; 3) fuerte interacción entre las comunidades locales y el patrimonio natural, y; 4) facilidad de acceso a los geositios.

Palabras clave: geodiversidad, geoconservación, geopatrimónio.

\section{INTRODUÇÃO}

O município de Prudentópolis se localiza no estado do Paraná e seu território possui um patrimônio natural diverso, principalmente no que se refere aos seus elementos geológicos e geomorfológicos. Sua geodiversidade inclui afloramentos de rochas paleozoicas e mesozoicas da Bacia Sedimentar do Paraná, onde escarpas, cânions, cachoeiras e feições de relevo ruiniforme criaram um cenário singular.

A geodiversidade é definida por Gray (2013, p.12), como "a variedade natural (diversidade) de elementos geológicos (rochas, minerais, fósseis), geomorfológicos (formas de relevo, topografia, processos físicos), solos e características hidrológicas. Também inclui suas assembleias, estruturas, sistemas e contribuições para a paisagem". O conjunto de locais onde ocorrem elementos da geodiversidade com características especiais, dotados de valores científicos, educativos, culturais, turísticos ou outros, representa o patrimônio geológico de um território (Gray, 2004; Brilha, 2005; Nascimento, Azevedo \& MantessoNeto, 2008).

Brilha (2005, p.52) propôs que "o patrimônio geológico é definido como o conjunto de geossítios inventariados e caracterizados numa dada região" onde, geossítio seria a "ocorrência de um ou mais elementos da geodiversidade, bem delimitado geograficamente e que apresente valor singular do ponto de vista científico, pedagógico, cultural, turístico ou outro". No entanto, em trabalhos posteriores, Brilha (2016) sugeriu que o termo geossítio fosse aplicado somente aos locais com valor científico, indicando "ponto da geodiversidade" para se referir aos sítios com outros valores. Nesta pesquisa foi mantido o conceito amplo de geossítio, que inclui os múltiplos valores que destacam a excepcionalidade da definição.

Diferentemente, Rodrigues e Fonseca (2008) consideraram o geopatrimônio como a geodiversidade do território que apresenta um conjunto de valores especiais, sendo constituído por todo o conjunto de elementos naturais abióticos existentes na superfície da Terra que devem ser conservados devido ao seu valor patrimonial. Para a maioria dos autores, no entanto, o geopatrimônio é sinônimo de patrimônio geológico com base na contração de geological heritage para geoheritage (Brilha apud Liccardo \& Guimarães, 2018). Este é o conceito adotado neste levantamento, sendo o geopatrimônio, portanto, o conjunto de geossítios levantados em Prudentópolis e a base para possíveis estratégias de implantação de geoturismo, geoconservação ou geoparque nesse território. 
Para Ruchkys (2007) o geopatrimônio é o principal atrativo para a atividade geoturística, cujo objetivo seria, no conceito de Hose (1995), facilitar o entendimento e oferecer facilidades de serviços para que turistas adquiram conhecimentos da geologia e geomorfologia de um local, indo além de meros espectadores de uma beleza estética. Essa atividade visa a conservação dos atrativos naturais, assim como o fomento da geoeducação a partir da popularização e divulgação das geociências (Dowling \& Newsome, 2018), devendo funcionar de forma integrada com a comunidade local para possibilitar o seu desenvolvimento econômico (Gray, 2018).

\section{MATERIAIS E MÉTODOS}

A metodologia desta pesquisa parte do levantamento bibliográfico em torno dos conceitos relacionados a geodiversidade, geopatrimônio e geoturismo; levantamento cartográfico; investigações de campo destinadas ao reconhecimento da paisagem; e espacialização e georreferenciamento dos pontos de interesse, com auxílio de um receptor GPS (Global Positioning System) e registros fotográficos e de vídeo.

Tendo em vista a grande extensão territorial e diversidade abiótica de Prudentópolis, o estudo cartográfico anterior às investigações de campo se mostrou essencial, auxiliando na localização e identificação preliminar de alguns geossítios. Os trabalhos de campo, realizados entre outubro de 2018 e fevereiro de 2019, permitiram o reconhecimento de 19 pontos com características especiais em meio à geodiversidade (geossítios). Foram incluídos aqueles que já fazem parte do roteiro turístico oferecido pela prefeitura de Prudentópolis ${ }^{1}$, buscando assim, um maior e mais rápido contato dos visitantes com as informações geocientíficas sistematizadas.

Para a análise do potencial turístico do geopatrimônio levantado foram considerados os seguintes aspectos: (a) Unidade geológica em que se enquadra; (b) Atrativo geológico e geomorfológico; (c) Valores que apresenta (Gray, 2004)²; (d) Acessibilidade; (e) Infraestrutura turística; e (f) Condições relativas à conservação.

A sistematização de informações sobre a geodiversidade do território e a seleção dos geossítios serviu de base para a criação de materiais didáticos e de divulgação - mapa geoturístico e vídeo educativo - auxiliares na disseminação deste conteúdo para a sociedade.

\section{O MUNICÍPIO DE PRUDENTÓPOLIS}

Prudentópolis localiza-se na mesorregião sudeste do Paraná, sul do Brasil (Fig. 1), com área territorial de $2.242,46 \mathrm{~km}^{2}$ e distante aproximadamente $200 \mathrm{~km}$ da capital do estado, Curitiba (Instituto Paranaense de Desenvolvimento Econômico e Social [IPARDES], 2020). Seus principais acessos são a BR-373 (Ponta Grossa - Prudentópolis) e a BR-277 (Curitiba - Prudentópolis e Guarapuava - Prudentópolis).

1 Disponível em http://turismoprudentopolis.com.br/

2 Os valores da geodiversidade de Gray (2004) - intrínseco, cultural, estético, econômico, funcional e científico/educativo nortearam essa investigação, e permeiam o contexto geológico e geomorfológico do município. 
Figura 1: Localização do município de Prudentópolis, PR.
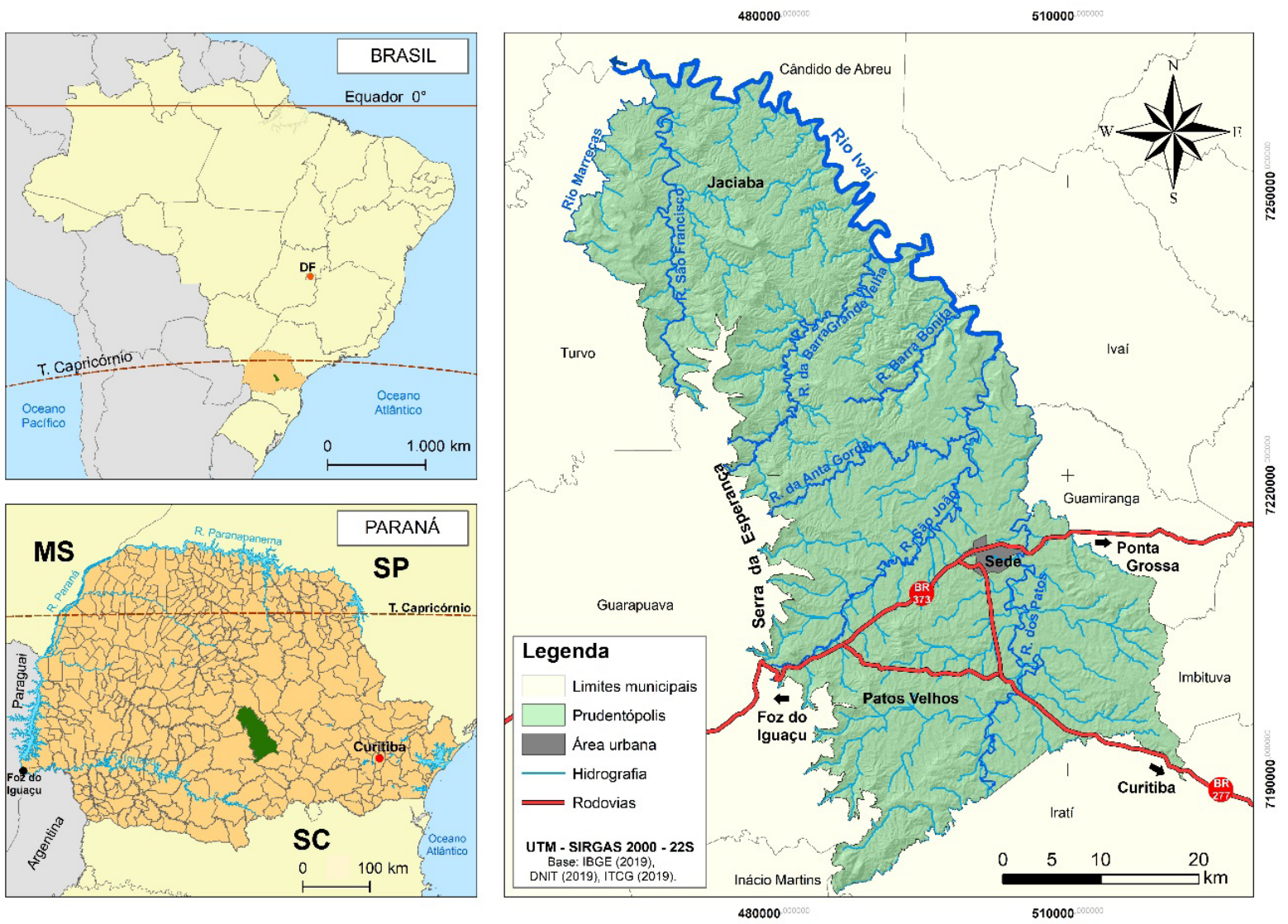

A ocupação da região se deu inicialmente por grupos indígenas, que deixaram marcas de sua passagem em artefatos arqueológicos cerâmicos e líticos datados de até 8 mil anos atrás. Posteriormente, assentaram-se grupos tropeiros à beira do "Caminho de Palmas", no trecho que ligava Guarapuava a Ponta Grossa. Não obstante, o desenvolvimento mais acentuado do município aconteceu a partir do século XIX com a chegada de imigrantes europeus, predominantemente ucranianos (Rogoski, 2020).

A atividade econômica básica do território é a produção agropecuária, principalmente a produção de grãos e de fumo, cultura esta que emprega essencialmente mão de obra familiar (Douhi, 2004). Outra importante atividade econômica para o município é o turismo, voltado para a cultura ucraniana presente na arquitetura, gastronomia e festividades, mas o segmento de mais evidência dessa atividade tem sido aquele ligado ao seu meio natural, em especial à geodiversidade.

O substrato rochoso de Prudentópolis constitui-se de unidades paleozoicas e mesozoicas da Bacia Sedimentar do Paraná (Quadro 1), originadas em momentos importantes da história da Terra, anterior a abertura do Oceano Atlântico Sul, nos domínios do supercontinente Pangea. O município se encontra dominantemente sobre rochas sedimentares paleozoicas do Grupo Passa Dois, sendo as rochas mais antigas, as da Formação Serra Alta (Permiano médio/inferior), que afloram com pouca expressão a leste do município. Em abrangência, predominam as Formações Teresina e Rio do Rasto (Permiano superior). Bordejando a Serra Geral, limite natural entre os Segundo do Terceiro Planaltos Paranaenses, 
estão presentes os arenitos das Formações Piramboia (Triássico) e Botucatu (Jurássico/ Cretáceo), assim como as rochas ígneas do Grupo Serra Geral (Cretáceo). Ocorrem também, extensas soleiras de diabásio (Cretáceo) na porção sul e sudeste do município.

Quadro 1 - Coluna Estratigráfica de Prudentópolis, com ilustração de cada unidade.

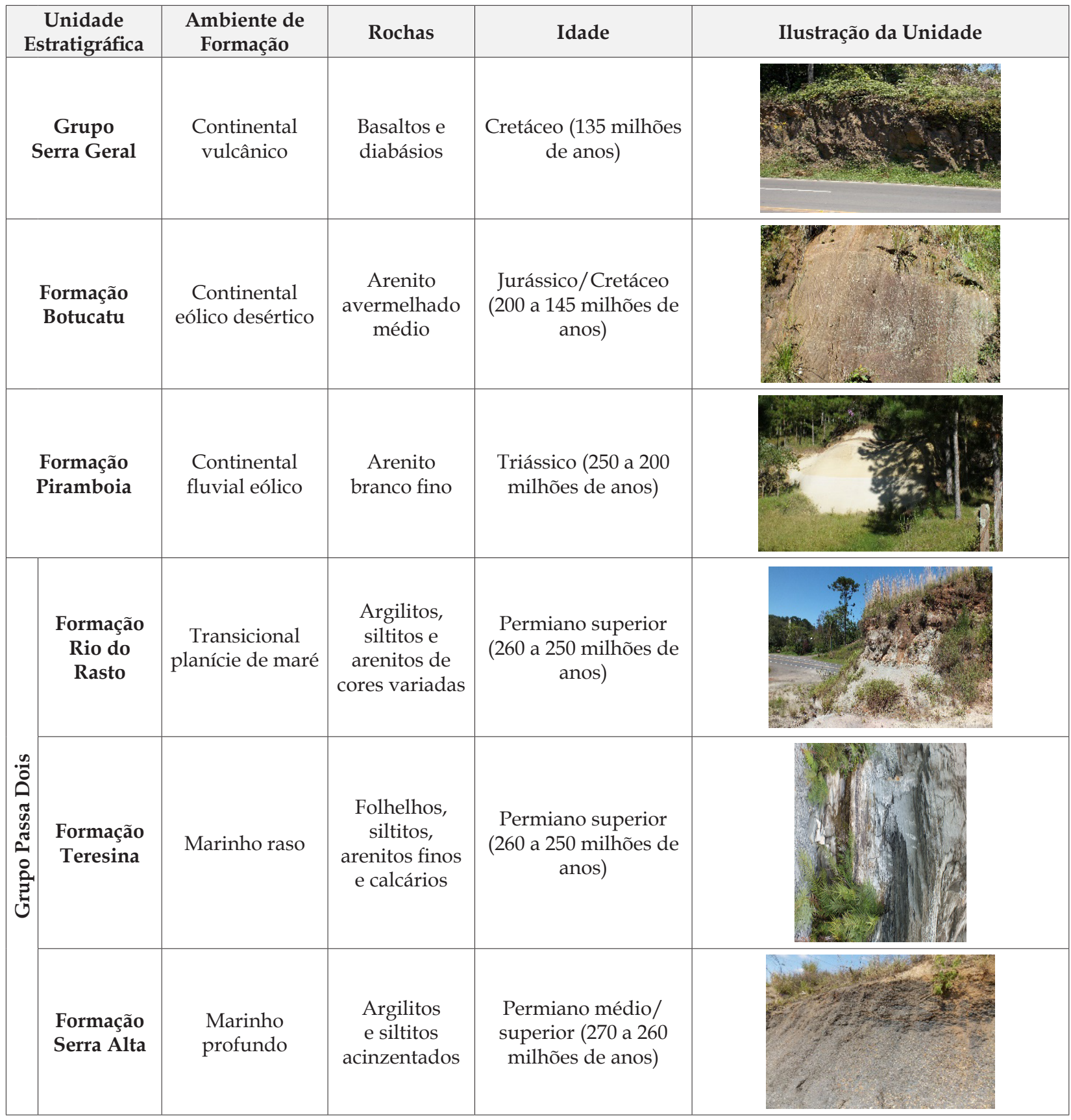

Sua localização geográfica, na transição morfoescultural do Segundo para o Terceiro Planaltos do Paraná, lhe confere uma paisagem singular, com centenas de cachoeiras, sendo que grande parte delas ultrapassa a centena de metros de altura (Prudentópolis, 2015), diversos morros testemunhos, e geoformas singulares, que permitem o entendimento básico sobre a origem e evolução do relevo regional. 
Os fatores que influenciam a grande quantidade de quedas d'agua estão diretamente ligados à sua geodiversidade, o que lhe rendeu o título de "Terra das Cachoeiras Gigantes", principais atrativos do município. Entre elas estão o Salto São Francisco (196m), os segmentos de rios em cânions representados por knickpoints do Salto São João (84m) e do Salto Barão do Rio Branco (64m), além dos morros Trombudo, Trombudinho e morro do Chapéu, resquícios da antiga posição da Escarpa da Serra da Esperança - nome local para a Serra Geral, que delimita o limite oeste do município.

Integra essa rica geodiversidade a junção dos rios dos Patos e São João, formadores do rio Ivaí, além de um destacado conteúdo paleontológico, como o geossítio Pinheiro de Pedra, que apresenta lenhos de coníferas silicificados entre as rochas da Formação Teresina.

As classes de solo que predominam no município são Neossolos regolíticos e litólicos, Nitossolos, Argissolos e Latossolos (Instituto de Terras e Cartografia [ITCG], 2018). No território, o relevo condiciona o uso do solo, predominando a agricultura na porção sul do município e, em razão das altas declividades da porção norte, a prática da pecuária.

No que diz respeito aos aspectos fitogeográficos, Prudentópolis está inserida no bioma da Mata Atlântica, com cobertura vegetal formada pela Floresta Ombrófila Mista Montana (no Segundo Planalto Paranaense) e Floresta Ombrófila Mista Alto-Montana (no Terceiro Planalto Paranaense), além da Floresta Ombrófila Mista Aluvial ocupando as margens dos principais rios do município (Instituto Brasileiro de Geografia e Estatística [IBGE], 1992).

\section{GEOPATRIMÔNIO DE PRUDENTÓPOLIS}

A partir do reconhecimento da geodiversidade, foram espacializados 19 geossítios (Fig. 2), descritos e ilustrados na sequência (Figs. 3, 4 e 5).

\section{1 - Pedreira da Formação Teresina}

As rochas predominantes são os folhelhos, siltitos, argilitos e arenitos finos da Formação Teresina, rochas que se formaram em ambiente marinho raso no Permiano superior, há aproximadamente 250 milhões de anos. Estas rochas preservam feições como marcas onduladas, gretas de contração, coquinas, conchas de bivalves e estromatólitos, importantes testemunhos da história evolutiva do planeta.

\section{2 - Salto Manduri}

Sobre o rio dos Patos, o Salto Manduri constitui uma quebra de relevo sobre rochas da Formação Teresina, com queda d'água de aproximadamente 34m de altura e 100m de extensão. Seu potencial hidráulico é utilizado parcialmente para geração de energia por uma pequena central hidrelétrica $(\mathrm{PCH})$.

\section{3 - Salto Barão do Rio Branco}

O Salto Barão do Rio Branco constitui uma quebra abrupta de relevo sobre rochas da Formação Teresina com uma soleira de diabásio, além de uma queda d'água de 64m de altura sobre o rio dos Patos. 
Figura 2 - Mapa geológico com localização dos geossítios, Prudentópolis, PR.
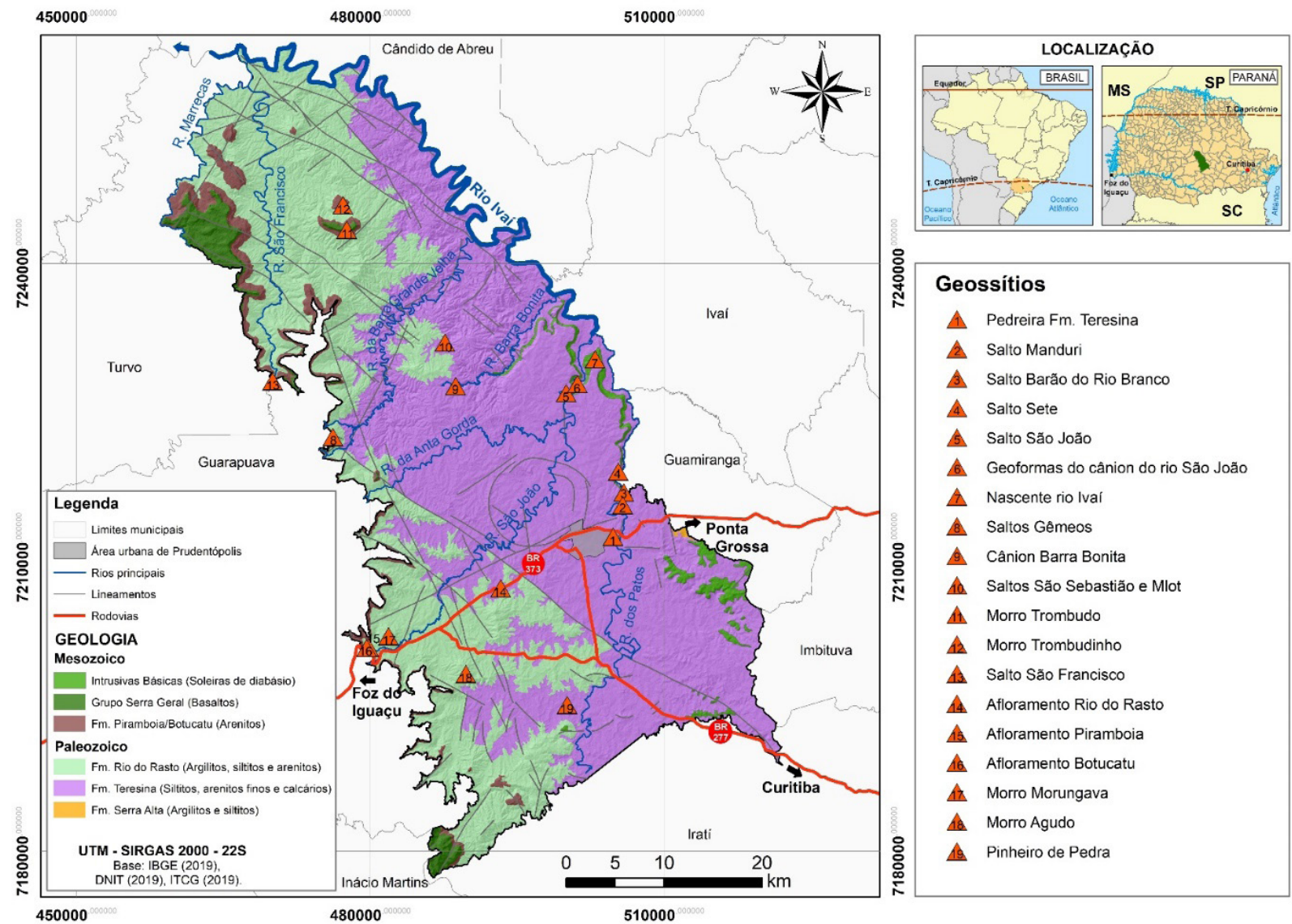

A Pedreira Fm. Teresina

2 Salto Manduri

3. Salto Barão do Rio Branco

4 Salto Sete

(5) Salto São João

¿ Geoformas do cânion do rio São João

A Nascente rio Ivaí

B. Saltos Gêmeos

A. Cânion Barra Bonita

40. Saltos São Sebastião e Mlot

A. Morro Trombudo

4. Morro Trombudinho

1 Salto São Francisco

4 Afloramento Rio do Rasto

As Afloramento Piramboia

16 Afloramento Botucatu

At Morro Morungava

18 Morro Agudo

19 Pinheiro de Pedra

\section{4 - Salto Sete}

O Salto Sete, com 77m de altura, é uma das principais cachoeiras ao longo do cânion do rio dos Patos. O cânion é uma garganta que foi escavada ao longo de milhões de anos nas rochas da Formação Teresina, e também uma soleira de diabásio.

\section{5 - Salto São João}

O Salto São João é outra cachoeira formada no contexto das soleiras de diabásio entre rochas da Formação Teresina. A queda d'água de $84 \mathrm{~m}$ de altura está sobre o rio São João, protegida pela Unidade de Conservação Monumento Natural Salto São João.

\section{6 - Geoformas do Cânion do rio São João}

Ao longo do cânion do rio São João é comum a presença de morros testemunhos e feições ruiniformes. Essas geoformas esculpidas em siltitos da Formação Teresina são associadas a imagens conhecidas pela comunidade, como no caso da "Cabeça do Lobo". 
Figura 3 - Imagens dos geossítios: 1- Pedreira da Formação Teresina; 2- Salto Manduri; 3- Salto Barão do Rio Branco; 4- Salto Sete; 5- Salto São João; 6- Geoformas do Cânion do rio São João; 7- Vista para nascente do rio Ivaí; 8- Saltos Gêmeos, Prudentópolis, PR.

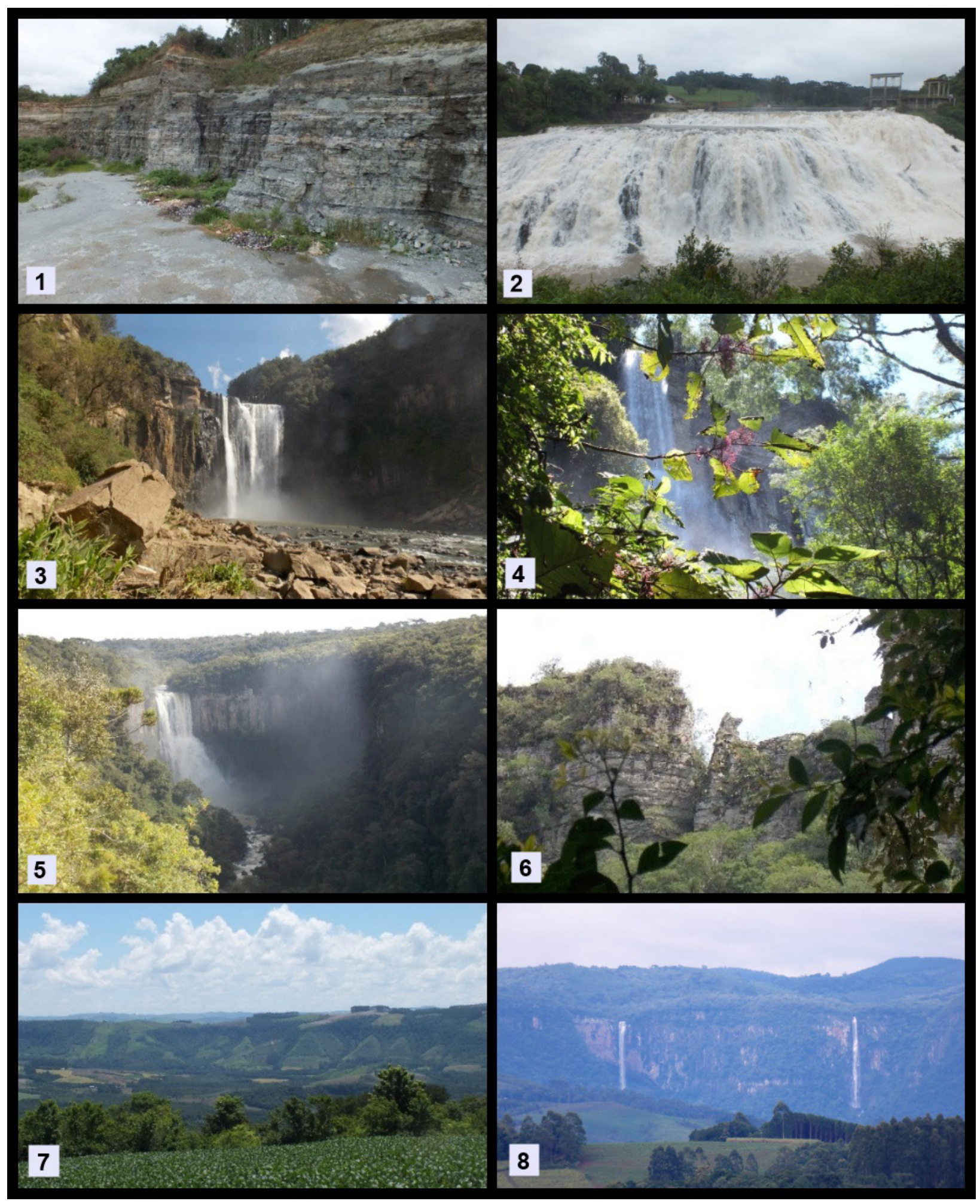




\section{7 - Vista para nascente do rio Ivaí}

Desse local é possível observar a confluência entre o rio dos Patos e o rio São João, formadores do rio Ivaí. Observa-se uma grande área de várzea, cachoeiras de menor porte ao longo das escarpas dos vales em "V", deposições de tálus (rampas) em formas trapezoidais e os diferentes usos da terra.

\section{8 - Saltos Gêmeos}

Os Saltos Barra Grande (130m) e Fazenda Velha (100m) deságuam sobre o degrau geológico-geomorfológico que marca a transição entre os Segundo e Terceiro Planaltos Paranaenses - na região chamada Serra da Esperança.

\section{9 - Cânion Barra Bonita}

Garganta escavada pela ação das águas sobre as rochas da Formação Teresina, onde se forma um conjunto de quedas d'água e lapas. O cânion se inicia na propriedade da família Perehouski e se estende até a RPPN Ninho do Corvo.

\section{0 - Salto São Sebastião e Mlot}

Duas quedas d'água frente a frente, sobre as rochas da Formação Teresina. Descontinuidades tectônicas e processos de erosão fluvial deram origem a essas duas cachoeiras.

\section{1 - Morro Trombudo; 12 - Morro Trombudinho}

Morros testemunhos associados ao recuo erosivo da Serra da Esperança, sustentados por uma camada de maior resistência aos agentes intempéricos (basaltos e arenitos).

\section{3- Salto São Francisco}

O Salto São Francisco se forma a partir da Serra da Esperança e possui 196m de altura, sendo a maior cachoeira da região sul do Brasil. Nesse ponto é possível observar a interação entre as rochas vulcânicas do Grupo Serra Geral e as rochas areníticas do paleodeserto Botucatu - Intertrapp.

\section{4 - Afloramento Rio do Rasto}

A Formação Rio do Rasto constitui-se por sedimentos arenosos e argilosos de cores variadas. Suas rochas, de paleoambiente transicional de planície de marés, são testemunhos da passagem de ambiente marinho para o continental num processo regressivo e se formaram no período Permiano Superior (aproximadamente 250 milhões de anos). 


\section{5 - Afloramento Piramboia}

A Formação Piramboia, do período Triássico (250 a 200 milhões de anos) apresenta rochas formadas em ambiente fluvial eólico. São arenitos brancos e finos com grãos angulosos e arredondados, apresentando quantidade de argila em sua composição.

\section{6- Afloramento Botucatu}

A Formação Botucatu constitui-se essencialmente por arenitos médios a finos de elevada esfericidade e aspecto fosco avermelhado. Suas características apontam para uma deposição eólica em ambiente desértico no período Jurássico e início do Cretáceo (200 a 145 milhões de anos). Juntamente com a Formação Piramboia constituem o Sistema Aquífero Guarani.

\section{7 - Morro Morungava (Morro do Chapéu)}

Mais conhecido como Morro do Chapéu, devido a sua forma, é um morro testemunho com superfície mais resistente à atividade erosiva, situado próximo ao front da Serra da Esperança.

\section{8 - Morro Agudo}

Um dos principais atrativos da Linha Rural de Tijuco Preto, o Morro Agudo é mais uma prova da antiga posição da cuesta em relação ao relevo. Possui um nível altimétrico de aproximadamente $1.060 \mathrm{~m}$, sendo representado pelas litologias do Grupo Serra Geral (basaltos) e Formações Piramboia e Botucatu (arenitos).

\section{9 - Pinheiros de Pedra}

A fossilização dessas árvores aconteceu imediatamente após a queda dos troncos, seja em ambiente de deposição de sedimentos ou durante um soterramento. Com o soterramento rápido e a ausência de oxigênio, ocorreu o processo de mineralização, onde a matéria orgânica presente nos troncos foi substituída por sílica (dióxido de silício - $\mathrm{SiO}_{2}$ ), a substância predominante. 
Figura 4 - Imagens dos geossítios selecionados: 9- Cânion Barra Bonita; 10- Salto São Sebastião e Mlot; 11- Morro Trombudo; 12- Morro Trombudinho; 13- Salto São Francisco; 14- Afloramento Rio do Rasto; 15Afloramento Piramboia; 16- Afloramento Botucatu, Prudentópolis, PR.

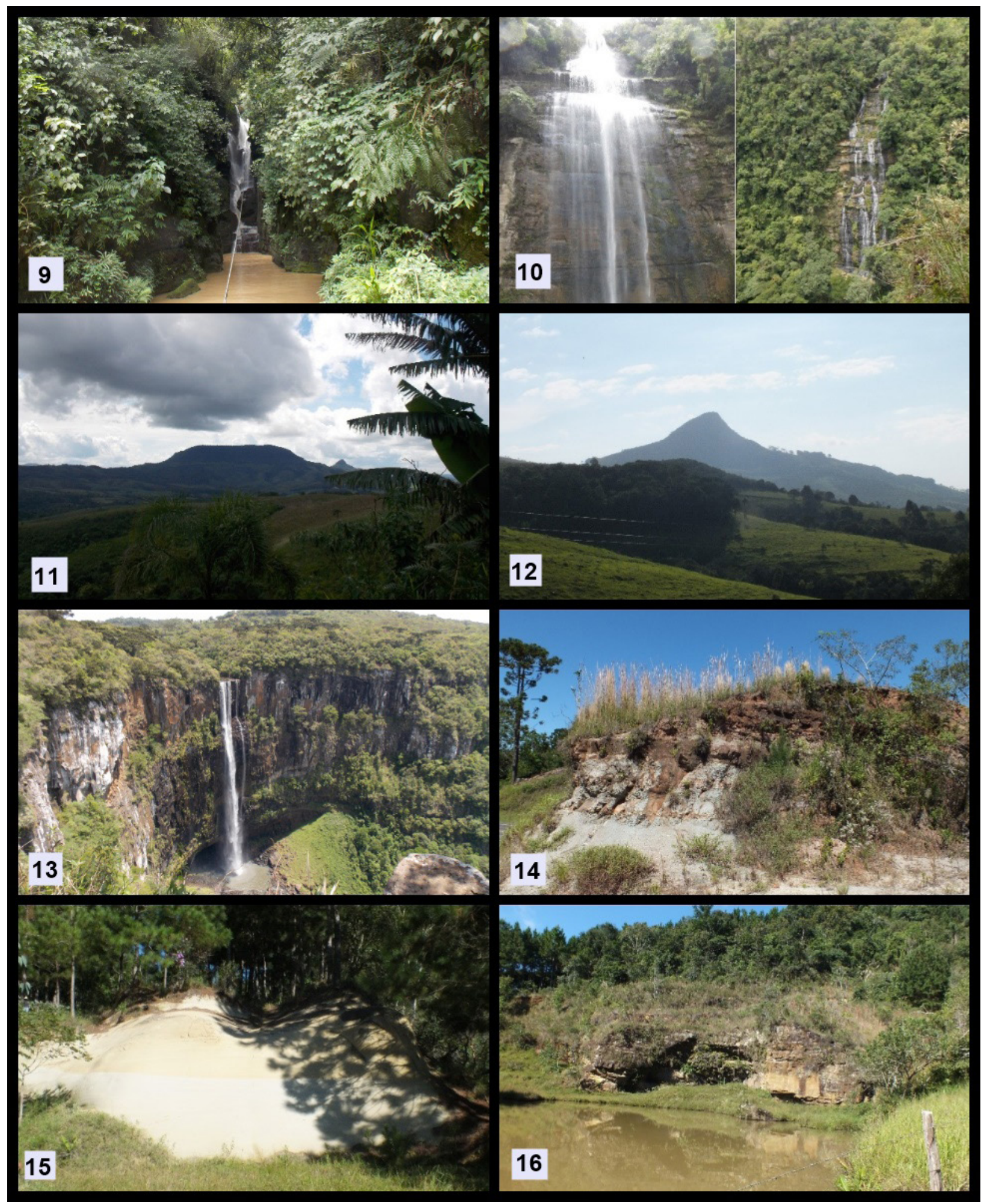


Figura 5 - Imagens dos geossítios selecionados: 17- Morro Morungava (Morro do Chapéu); 18- Morro Agudo; 19- Pinheiros de Pedra, Prudentópolis, PR.

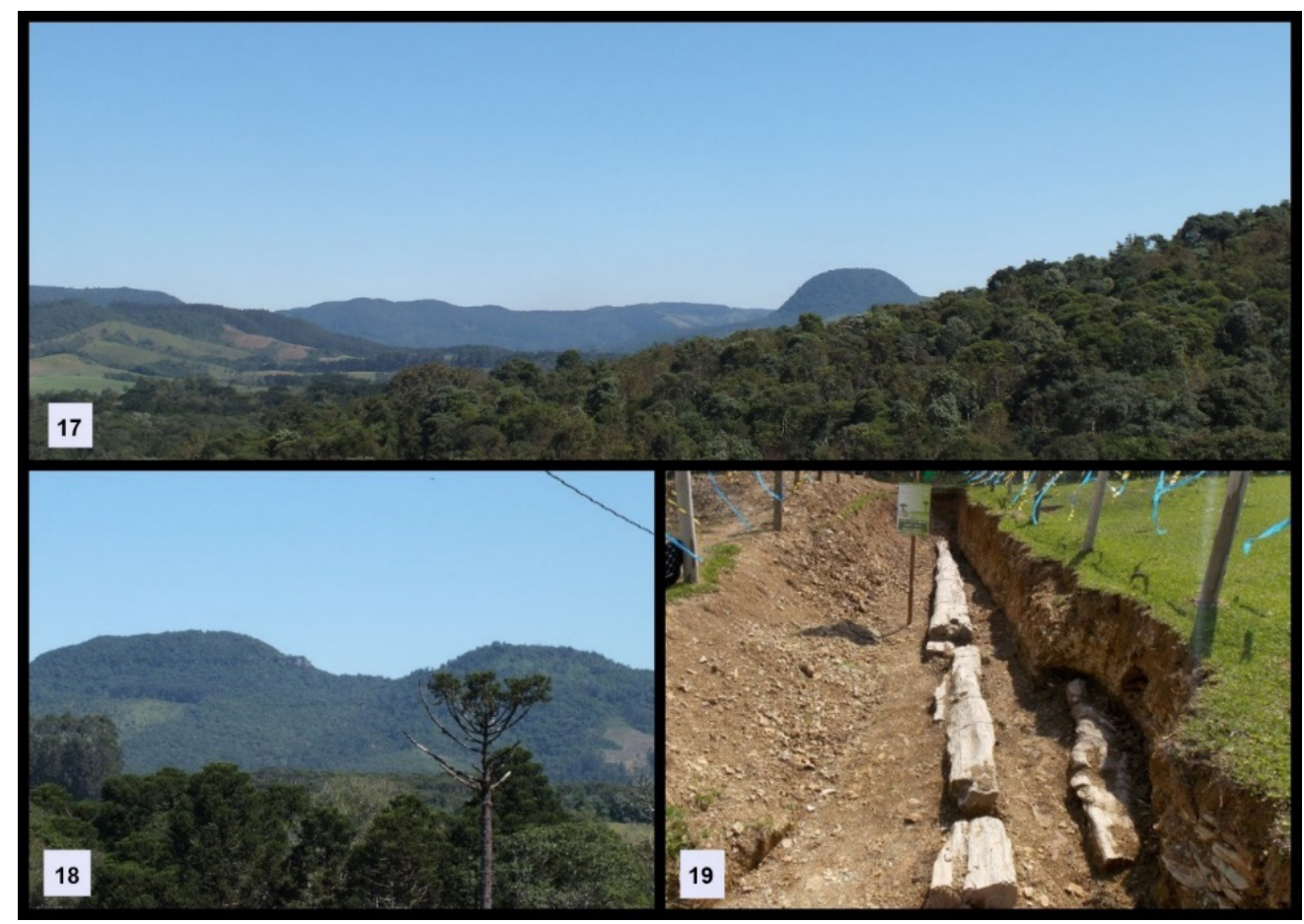

\section{GEOTURISMO EM PRUDENTÓPOLIS}

Para que a educação em geociências seja bem sucedida é necessário o contato direto com a geodiversidade, conforme Brilha (2005). Os geossítios propostos neste levantamento tornam possível esse contato de maneira direta e acessível, já que a maioria possui fácil acesso com estradas em boas condições.

A geodiversidade do município de Prudentópolis cria cenários e paisagens singulares que chamam a atenção de visitantes e turistas. Com a crescente evolução do turismo como atividade econômica o município vem ampliando o seu suporte para esta atividade, investindo em infraestrutura e meios de divulgação. O Quadro 2 sintetiza e ilustra o potencial do geopatrimônio de Prudentópolis para o desenvolvimento da atividade geoturística. 
Quadro 2: Geossítios e a disponibilidade de informações para o geoturismo.

\begin{tabular}{|c|c|c|c|c|c|c|c|}
\hline GEOSSÍTIOS & ATRATIVO & \begin{tabular}{|l|} 
UNIDADE \\
GEOLÓGICA \\
\end{tabular} & $\begin{array}{l}\text { CONTEXTO GEOL/ } \\
\text { GEOMORF } \\
\end{array}$ & \begin{tabular}{|l|} 
VALORES \\
PREDOMINANTES \\
\end{tabular} & ACESSIBILIDADE & \begin{tabular}{|l|} 
INFRAESTRUTURA \\
TURISTICA
\end{tabular} & CONSERVAÇÃO \\
\hline $\begin{array}{l}\text { Pedreira da F. } \\
\text { Teresina }\end{array}$ & $\begin{array}{l}\text { Camadas } \\
\text { de rochas } \\
\text { sedimentares } \\
\text { em corte }\end{array}$ & $\begin{array}{l}\text { Formação } \\
\text { Teresina } \\
\text { (250 Ma.) }\end{array}$ & $\begin{array}{l}\text { Rochas de ambiente } \\
\text { marinho formadas } \\
\text { no período Permiano } \\
\text { Superior. }\end{array}$ & Científico/Didático & $\begin{array}{l}\text { Estrada de terra } \\
(2 \mathrm{~km}) \text { ao lado da } \\
\text { BR-376. }\end{array}$ & Não apresenta & Regular \\
\hline Salto Manduri & $\begin{array}{l}\text { Queda d'água } \\
(34 \mathrm{~m} \text { altura } \\
\text { x } 100 \mathrm{~m} \\
\text { extensão) }\end{array}$ & $\begin{array}{l}\text { Formação } \\
\text { Teresina } \\
(250 \text { Ma.) }\end{array}$ & $\begin{array}{l}\text { Quebra abrupta de } \\
\text { relevo sobre rochas da } \\
\text { Formação Teresina, } \\
\text { com queda d'água. }\end{array}$ & $\begin{array}{l}\text { Estético } \\
\text { Funcional } \\
\text { Científico/Didático }\end{array}$ & $\begin{array}{l}\text { Estrada de terra } \\
(3,5 \mathrm{~km}) \text { em boas } \\
\text { condições ao lado da } \\
\text { BR-376. }\end{array}$ & $\begin{array}{l}\text { Mirante, lanchonete, } \\
\text { piscina, espaço } \\
\text { recreativo } \\
\text { (Recanto Rickli) }\end{array}$ & Bom \\
\hline $\begin{array}{l}\text { Salto Barão do } \\
\text { Rio Branco }\end{array}$ & $\begin{array}{l}\text { Queda d'água } \\
(64 \mathrm{~m})\end{array}$ & $\begin{array}{l}\text { Formação } \\
\text { Teresina } \\
\text { (250 Ma.) e } \\
\text { Soleira (135 Ma.) }\end{array}$ & $\begin{array}{l}\text { Quebra abrupta de } \\
\text { relevo sobre rochas } \\
\text { da Formação Teresina } \\
\text { e uma soleira de } \\
\text { diabásio, com queda } \\
\text { d'água. }\end{array}$ & $\begin{array}{l}\text { Estético } \\
\text { Funcional } \\
\text { Científico/Didático }\end{array}$ & $\begin{array}{l}\text { Estrada de terra } \\
(4 \mathrm{Km}) \text { em boas } \\
\text { condições ao lado da } \\
\text { BR-376. }\end{array}$ & $\begin{array}{l}\text { Mirante e escada } \\
\text { de acesso em mau } \\
\text { estado. }\end{array}$ & Bom \\
\hline Salto Sete & $\begin{array}{l}\text { Queda d'água } \\
(77 \mathrm{~m})\end{array}$ & $\begin{array}{l}\text { Formação } \\
\text { Teresina } \\
\text { (250 Ma.) e } \\
\text { Soleira (135 Ma.) }\end{array}$ & $\begin{array}{l}\text { Cachoeira na borda } \\
\text { do cânion do rio dos } \\
\text { Patos, uma garganta } \\
\text { escavada nas rochas } \\
\text { pela ação das águas. }\end{array}$ & $\begin{array}{l}\text { Estético } \\
\text { Científico/Didático }\end{array}$ & $\begin{array}{l}\text { Asfalto }(6 \mathrm{~km}) \text { e } \\
\text { estrada de terra } \\
(7,5 \mathrm{~km}) \text { em boas } \\
\text { condições; Trilhas } \\
\text { com dificuldade } \\
\text { moderada. }\end{array}$ & $\begin{array}{l}\text { Mirante, trilhas, } \\
\text { hospedagem e } \\
\text { restaurante. }\end{array}$ & Bom \\
\hline Salto São João & $\begin{array}{l}\text { Queda d'água } \\
(86 \mathrm{~m})\end{array}$ & $\begin{array}{l}\text { Formação } \\
\text { Teresina } \\
\text { (250 Ma.) e } \\
\text { Soleira (135 Ma.) }\end{array}$ & $\begin{array}{l}\text { Cachoeira formada no } \\
\text { contexto das soleiras } \\
\text { de diabásio entre } \\
\text { rochas da Formação } \\
\text { Teresina. }\end{array}$ & $\begin{array}{l}\text { Estético } \\
\text { Científico/Didático }\end{array}$ & $\begin{array}{l}\text { Estrada de } \\
\text { calçamento }(22 \mathrm{~km} \text { a } \\
\text { partir da sede); } \\
\text { Trilhas fáceis. }\end{array}$ & $\begin{array}{l}\text { Mirante, trilhas e } \\
\text { centro de informações } \\
\text { turísticas. }\end{array}$ & Bom \\
\hline $\begin{array}{l}\text { Geoformas do } \\
\text { cânion do rio } \\
\text { São João }\end{array}$ & $\begin{array}{l}\text { Geoformas no } \\
\text { cânion do rio } \\
\text { São João. }\end{array}$ & $\begin{array}{l}\text { Formação } \\
\text { Teresina } \\
\text { (250 Ma.) e } \\
\text { Soleira (135 Ma.) } \\
\end{array}$ & $\begin{array}{l}\text { Morros testemunho } \\
\text { com feições } \\
\text { ruiniformes; ilhas; } \\
\text { cachoeiras. }\end{array}$ & $\begin{array}{l}\text { Cultural } \\
\text { Estético } \\
\text { Científico/Didático }\end{array}$ & $\begin{array}{l}5 \text { Km do Salto } \\
\text { São João; Trilhas } \\
\text { de dificuldade } \\
\text { moderada. }\end{array}$ & Não apresenta & Bom \\
\hline $\begin{array}{l}\text { Vista para a } \\
\text { nascente do rio } \\
\text { Ivaí }\end{array}$ & \begin{tabular}{|l} 
Vista \\
panorâmica \\
para a \\
nascente do \\
rio Ivaí. \\
\end{tabular} & $\begin{array}{l}\text { Formação } \\
\text { Teresina } \\
\text { (250 Ma.) e } \\
\text { Soleira (135 Ma.) }\end{array}$ & $\begin{array}{l}\text { Confluência entre o rio } \\
\text { dos Patos e o rio São } \\
\text { João, formadores do } \\
\text { rio Ivaí. }\end{array}$ & $\begin{array}{l}\text { Estético } \\
\text { Funcional } \\
\text { Científico/Didático }\end{array}$ & $\begin{array}{l}6 \mathrm{~km} \text { de estrada de } \\
\text { terra a partir do Salto } \\
\text { São João. }\end{array}$ & Não apresenta & Regular \\
\hline Saltos Gêmeos & $\begin{array}{l}\text { Vista } \\
\text { panorâmica } \\
\text { da Escarpa da } \\
\text { Esperança e } \\
\text { Saltos Gêmeos } \\
\text { (100 e 130 } \\
\text { metros) }\end{array}$ & $\begin{array}{l}\text { Grupo Serra } \\
\text { Geral (135 Ma.) }\end{array}$ & $\begin{array}{l}\text { Degrau geológico- } \\
\text { geomorfológico que } \\
\text { marca a transição entre } \\
\text { o Segundo do Terceiro } \\
\text { Planaltos Paranaenses, } \\
\text { onde se formam duas } \\
\text { cachoeiras de grande } \\
\text { porte. }\end{array}$ & $\begin{array}{l}\text { Estético } \\
\text { Científico/Didático }\end{array}$ & $\begin{array}{l}\text { Pode ser observada } \\
\text { das estradas que } \\
\text { ligam ao norte do } \\
\text { município ( } 18 \mathrm{~km} \text { a } \\
\text { partir da sede) }\end{array}$ & Não apresenta & Bom \\
\hline $\begin{array}{l}\text { Cânion Barra } \\
\text { Bonita }\end{array}$ & $\begin{array}{l}\text { Cânion, } \\
\text { cascatas e } \\
\text { lapas. }\end{array}$ & $\begin{array}{l}\text { Formação } \\
\text { Teresina } \\
\text { (250 Ma.) }\end{array}$ & $\begin{array}{l}\text { Cânion com quedas } \\
\text { d'água e lapas, } \\
\text { associadas ao } \\
\text { contexto tectônico } \\
\text { (falhas-fraturas), } \\
\text { litologias e processos } \\
\text { de erosão fluvial. } \\
\end{array}$ & $\begin{array}{l}\text { Estético } \\
\text { Científico/Didático }\end{array}$ & $\begin{array}{l}25 \mathrm{~km} \text { a partir da sede } \\
(13 \mathrm{~km} \text { asfalto; } 12 \mathrm{~km} \\
\text { estrada de terra em } \\
\text { boas condições pela } \\
\text { linha Paraná) }\end{array}$ & $\begin{array}{l}\text { Recanto Perehouski: } \\
\text { Trilhas, quiosques e } \\
\text { camping. } \\
\text { RPPN Ninho do } \\
\text { Corvo: Hospedagem } \\
\text { e turismo de } \\
\text { aventura. }\end{array}$ & Bom \\
\hline $\begin{array}{l}\text { Salto São } \\
\text { Sebastião e } \\
\text { Mlot }\end{array}$ & $\begin{array}{l}\text { Quedas } \\
\text { d'água } \\
(130 \text { e } 120 \mathrm{~m})\end{array}$ & $\begin{array}{l}\text { Formação } \\
\text { Teresina } \\
\text { (250 Ma.) }\end{array}$ & $\begin{array}{l}\text { Duas cachoeiras frente } \\
\text { a frente originadas } \\
\text { pelo recuo do relevo } \\
\text { e processos de erosão } \\
\text { fluvial. }\end{array}$ & $\begin{array}{l}\text { Estético } \\
\text { Científico/Didático }\end{array}$ & $\begin{array}{l}\text { 30km a partir da sede } \\
(13 \mathrm{~km} \text { asfalto; } 17 \mathrm{~km} \\
\text { estrada de terra em } \\
\text { boas condições pela } \\
\text { linha Paraná) }\end{array}$ & Mirante e trilhas & Bom \\
\hline
\end{tabular}


conclusão

\begin{tabular}{|c|c|c|c|c|c|c|c|}
\hline GEOSSÍTIOS & ATRATIVO & \begin{tabular}{|l|} 
UNIDADE \\
GEOLÓGICA
\end{tabular} & $\begin{array}{l}\text { CONTEXTO GEOL/ } \\
\text { GEOMORF }\end{array}$ & \begin{tabular}{|l|} 
VALORES \\
PREDOMINANTES \\
\end{tabular} & ACESSIBILIDADE & $\begin{array}{l}\text { INFRAESTRUTURA } \\
\text { TURISTICA }\end{array}$ & CONSERVAÇÃO \\
\hline $\begin{array}{l}\text { Morro } \\
\text { Trombudo }\end{array}$ & $\begin{array}{l}\text { Morro } \\
\text { testemunho }\end{array}$ & $\begin{array}{l}\text { Grupo Serra } \\
\text { Geral (135 Ma.) }\end{array}$ & $\begin{array}{l}\text { Morro testemunho } \\
\text { associado ao recuo } \\
\text { erosivo da Escarpa da } \\
\text { Esperança, sustentado } \\
\text { por uma camada de } \\
\text { maior resistência aos } \\
\text { agentes intempéricos. }\end{array}$ & $\begin{array}{l}\text { Cultural } \\
\text { Estético } \\
\text { Científico/Didático }\end{array}$ & $\begin{array}{l}\text { Distrito de Ligação, } \\
55 \mathrm{~km} \text { da sede }(13 \mathrm{~km} \\
\text { de asfalto e } 42 \mathrm{~km} \text { de } \\
\text { estrada de terra em } \\
\text { boas condições) }\end{array}$ & Não apresenta & Bom \\
\hline $\begin{array}{l}\text { Morro } \\
\text { Trombudinho }\end{array}$ & $\begin{array}{l}\text { Morro } \\
\text { testemunho }\end{array}$ & $\begin{array}{l}\text { Formação } \\
\text { Botucatu (200 a } \\
145 \text { Ma.) }\end{array}$ & $\begin{array}{l}\text { Morro testemunho } \\
\text { associado ao recuo } \\
\text { erosivo da Escarpa da } \\
\text { Esperança, sustentado } \\
\text { por uma camada de } \\
\text { maior resistência aos } \\
\text { agentes intempéricos. }\end{array}$ & $\begin{array}{l}\text { Cultural } \\
\text { Estético } \\
\text { Funcional } \\
\text { Científico/Didático }\end{array}$ & $\begin{array}{l}\text { Distrito de Ligação, } \\
55 \mathrm{~km} \text { da sede }(13 \mathrm{~km} \\
\text { de asfalto e } 42 \mathrm{~km} \text { de } \\
\text { estrada de terra em } \\
\text { boas condições) }\end{array}$ & Não apresenta & Bom \\
\hline $\begin{array}{l}\text { Salto São } \\
\text { Francisco }\end{array}$ & $\begin{array}{l}\text { Queda d'água } \\
(196 \mathrm{~m})\end{array}$ & $\begin{array}{l}\text { Grupo Serra } \\
\text { Geral (135 Ma.) }\end{array}$ & $\begin{array}{l}\text { Queda d'água } \\
\text { formada a partir da } \\
\text { Escarpa da Esperança } \\
\text { com interação entre } \\
\text { as rochas vulcânicas } \\
\text { basálticas com os } \\
\text { sedimentos eólicos do } \\
\text { paleodeserto Botucatu. }\end{array}$ & $\begin{array}{l}\text { Estético } \\
\text { Científico/Didático }\end{array}$ & $\begin{array}{l}50 \mathrm{~km} \text { da sede }(13 \mathrm{~km} \\
\text { de asfalto e } 37 \mathrm{~km} \text { de } \\
\text { estrada de terra em } \\
\text { boas condições })\end{array}$ & Mirante e trilhas & Bom \\
\hline $\begin{array}{l}\text { Afloramento } \\
\text { Fm. Rio do } \\
\text { Rasto }\end{array}$ & $\begin{array}{l}\text { Rochas da } \\
\text { Formação Rio } \\
\text { do Rasto }\end{array}$ & $\begin{array}{l}\text { Formação Rio do } \\
\text { Rasto (250 Ma.) }\end{array}$ & $\begin{array}{l}\text { Rochas de ambiente } \\
\text { de planície de marés } \\
\text { formadas no período } \\
\text { permiano superior a } \\
250 \text { milhões de anos } \\
\text { atrás. } \\
\end{array}$ & Científico/Didático & $\begin{array}{l}\text { Comunidade São } \\
\text { Vicente de Paula, ao } \\
\text { lado da BR-373 }(11 \mathrm{~km} \\
\text { da sede) }\end{array}$ & Não apresenta & Bom \\
\hline $\begin{array}{l}\text { Afloramento } \\
\text { Fm. Piramboia }\end{array}$ & $\begin{array}{l}\text { Rochas da } \\
\text { Formação } \\
\text { Piramboia }\end{array}$ & $\begin{array}{l}\text { Formação } \\
\text { Piramboia (250 a } \\
200 \text { Ma.) }\end{array}$ & $\begin{array}{l}\text { Rochas de ambiente } \\
\text { fluvial eólico formadas } \\
\text { no período Triássico } \\
\text { entre } 250 \text { e } 200 \text { milhões } \\
\text { de anos atrás. } \\
\end{array}$ & $\begin{array}{l}\text { Funcional } \\
\text { Científico/Didático }\end{array}$ & $\begin{array}{l}\text { "Estrada velha" pela } \\
\text { Serra da Esperança } \\
\text { (3km de estrada de } \\
\text { terra em condição } \\
\text { moderada) } \\
\end{array}$ & Não apresenta & Bom \\
\hline $\begin{array}{l}\text { Afloramento } \\
\text { Fm. Botucatu }\end{array}$ & $\begin{array}{l}\text { Rochas da } \\
\text { Formação } \\
\text { Botucatu }\end{array}$ & $\begin{array}{l}\text { Formação } \\
\text { Botucatu (200 a } \\
145 \text { Ma.) }\end{array}$ & \begin{tabular}{|l|} 
Rochas de \\
paleoambiente \\
desértico formadas \\
entre os períodos \\
Triássico e Cretáceo \\
entre 200 e 145 milhões \\
de anos atrás. \\
\end{tabular} & $\begin{array}{l}\text { Funcional } \\
\text { Científico/Didático }\end{array}$ & $\begin{array}{l}\text { "Estrada velha" pela } \\
\text { Serra da Esperança } \\
\text { (3km de estrada de } \\
\text { terra em condição } \\
\text { moderada) }\end{array}$ & Não apresenta & Bom \\
\hline $\begin{array}{l}\text { Morro } \\
\text { Morungava } \\
\text { (Morro do } \\
\text { Chapéu) }\end{array}$ & $\begin{array}{l}\text { Morro } \\
\text { testemunho }\end{array}$ & $\begin{array}{l}\text { Grupo Serra } \\
\text { Geral (135 Ma.) }\end{array}$ & \begin{tabular}{|l|} 
Morro testemunho \\
com superfície mais \\
resistente a atividade \\
erosiva situado junto \\
ao front da Escarpa da \\
Esperança. \\
\end{tabular} & $\begin{array}{l}\text { Estético } \\
\text { Científico/Didático }\end{array}$ & $\begin{array}{l}\text { BR-277 a } 28 \mathrm{~km} \text { da } \\
\text { sede. }\end{array}$ & $\begin{array}{l}\text { Mirante da Serra da } \\
\text { Esperança. }\end{array}$ & Bom \\
\hline Morro Agudo & $\begin{array}{l}\text { Morro } \\
\text { testemunho }\end{array}$ & $\begin{array}{l}\text { Grupo Serra } \\
\text { Geral (135 Ma.) }\end{array}$ & $\begin{array}{l}\text { Morro testemunho, } \\
\text { provando a antiga } \\
\text { posição da cuesta em } \\
\text { relação ao relevo. }\end{array}$ & $\begin{array}{l}\text { Estético } \\
\text { Científico/Didático }\end{array}$ & $\begin{array}{l}\text { É observado da } \\
\text { BR-277, próximo } \\
\text { a comunidade } \\
\text { de Tijuco Preto } \\
\text { (aproximadamente } \\
\text { 25km da sede) } \\
\end{array}$ & Não apresenta & Bom \\
\hline $\begin{array}{l}\text { Pinheiros de } \\
\text { Pedra }\end{array}$ & $\begin{array}{l}\text { Lenhos fósseis } \\
\text { in situ }\end{array}$ & $\begin{array}{l}\text { Formação } \\
\text { Teresina } \\
\text { (250 Ma.) }\end{array}$ & $\begin{array}{l}\text { Árvores fossilizadas } \\
\text { pela substituição da } \\
\text { matéria orgânica por } \\
\text { sílica. }\end{array}$ & $\begin{array}{l}\text { Cultural } \\
\text { Científico/Didático }\end{array}$ & $\begin{array}{l}\text { Faxinal de } \\
\text { Taboãozinho a } 20 \mathrm{~km} \\
\text { da sede ( } 7 \mathrm{~km} \text { de } \\
\text { estrada de terra em } \\
\text { boas condições) }\end{array}$ & $\begin{array}{l}\text { Geossítio tombado e } \\
\text { criação de estrutura } \\
\text { turística em } \\
\text { andamento. }\end{array}$ & Bom \\
\hline
\end{tabular}


Observa-se que todos os geossítios possuem valor científico, visto que evidenciam parte da história da evolução do planeta. Suas formações geológicas estão relacionadas a diferentes paleoambientes, que vão desde marinhos até desérticos e vulcânicos. Suas rochas apresentam importantes registros de antigas formas de vida, com fósseis e icnofósseis, presentes principalmente nas rochas do Grupo Passa Dois (Formação Serra Alta, Teresina e Rio do Rasto), que apresentam grande relevância no estudo do Permiano da Bacia do Paraná (Neves, Rohn \& Simões, 2010), além dos excepcionais lenhos fosseis encontrados in situ entre camadas de rochas da Formação Teresina.

O valor didático também é bastante expressivo, pois o geopatrimônio de Prudentópolis constitui um laboratório prático para a educação em geociências, formal e não formal. Podem ser abordados conteúdos relacionados à geologia regional (Bacia do Paraná), o ciclo das rochas, evolução do relevo (Arco de Ponta Grossa) e geomorfologia fluvial, tectônica de placas, entre outros. Esses conteúdos podem ser acompanhados de discussões sobre educação ambiental e conservação da natureza.

Os geossítios estão, em geral, em bom estado de conservação, muitos já apresentando algum tipo de infraestrutura turística. No que diz respeito ao risco de degradação, ele é baixo nos locais protegidos por unidades de conservação, como é o caso do Salto São João e seu cânion, Salto São Francisco, Morro Morungava e Morro Agudo (APA da Serra da Esperança). É baixo também em geossítios que estão em propriedades particulares, mas são usados de forma sustentável pelo turismo, a exemplo do Salto Sete e Cânion Barra Bonita (RPPN Ninho do Corvo e Recanto Perehouski). Foram classificados como possuindo alto risco de degradação a nascente do rio Ivaí, ameaçada por atividades agrosilvopastoris, e os segmentos de rios em cânions dos rios dos Patos e São João, ameaçados por PCHs.

Ao discutir geoturismo não se pode deixar de lado as comunidades locais que vivem sobre o patrimônio natural. Em Prudentópolis as comunidades apresentam relações bastante expressivas com as geoformas, atribuindo diversos significados para a paisagem (Rogoski \& Smaha, 2017). Essa relação próxima da comunidade com a natureza fica mais evidente em ocasiões como o “Movimento Gigantes" em 2012, onde dezenas de estudantes se uniram contra as propostas de instalação de PCHs ao longo do rio dos Patos e rio São João, que afetariam as cachoeiras do município (Guil, 2015). Desde 2019, novos esforços da população em defesa das cachoeiras ainda vêm acontecendo. Esse sentimento de apropriação ou pertencimento é importante e pode tornar mais fácil a inserção da comunidade em projetos educativos e de geoconservação.

O benefício econômico para as comunidades locais também deve ser uma consequência do geoturismo (Nascimento, Azevedo \& Mantesso-Neto, 2008). A partir de observações ao longo da pesquisa percebe-se que diversas famílias começam a ver uma possibilidade de renda com o turismo, que vem ganhando força. O investimento em infraestrutura turística começa a beneficiar locais como o Salto Sete, Salto São Sebastião e Mlot, Recanto Perehouski, Pousada Salto São João, entre outros. Moradores do entorno desses locais também se beneficiam com a venda de produtos de suas propriedades, como mel, pão e biscoitos, produtos orgânicos, entre outros. 
Dos geossítios selecionados, grande parte apresenta considerável número de visitantes, principalmente as cachoeiras com infraestrutura. Isso constitui um ponto favorável para o geoturismo, que propõe oferecer uma nova camada de informações sobre a geodiversidade do território em locais que já desenvolvem atividades ligadas ao turismo.

\section{ESTRATÉGIAS DE DIVULGAÇÃO EM GEOCIÊNCIAS}

O conjunto de informações levantadas sobre a geodiversidade do território de Prudentópolis expôs um conteúdo valioso para a educação e cultura no município, o que permitiu a criação de materiais didáticos que apresentam os principais elementos da geodiversidade de Prudentópolis - mapa geoturístico e vídeo geoeducativo - com vistas a alcançar a comunidade de maneira não formal, e também contribuir no desenvolvimento de valores culturais da geodiversidade.

O mapa geoturístico (Fig. 6) procura expor o conteúdo científico e didático dos geossítios em linguagem simplificada, oferecendo ao visitante uma nova camada de informações - geocientíficas - ao atrativo. O mapa apresenta a geologia, geomorfologia e hidrografia do município. Seu conteúdo estratigráfico é representado em um quadro, onde são apresentadas suas formações geológicas e as principais rochas que as constituem, o paleoambiente de formação e a sua idade. As formações geológicas do município estão mescladas com o modelo digital do terreno, o que dá uma boa noção das principais formas do relevo de Prudentópolis. Ainda nesta espacialização são representados os mais importantes rios do território.

Na parte frontal do mapa apresentam-se as principais vias de acesso aos geossítios assim como imagens ilustrativas de seu geopatrimônio. O verso do mapa (Fig. 7) apresenta a localização do município em território brasileiro e na Bacia do Paraná, assim como imagens ilustrativas e uma descrição simplificada de cada geossítio. 
Figura 6 - Mapa Geoturístico de Prudentópolis, com indicação dos principais geossítios, rios e acessos.

\section{Geopatrimônio de Prudentópolis - PR Mapa Geoturístico}

Conheça a geodiversidade e o geopatrimônio de Prudentópolis. Suas cachociras, canyons, fósscis e diferentes tipos de rochas contam um pouco da história e evolução do nosso planeta.
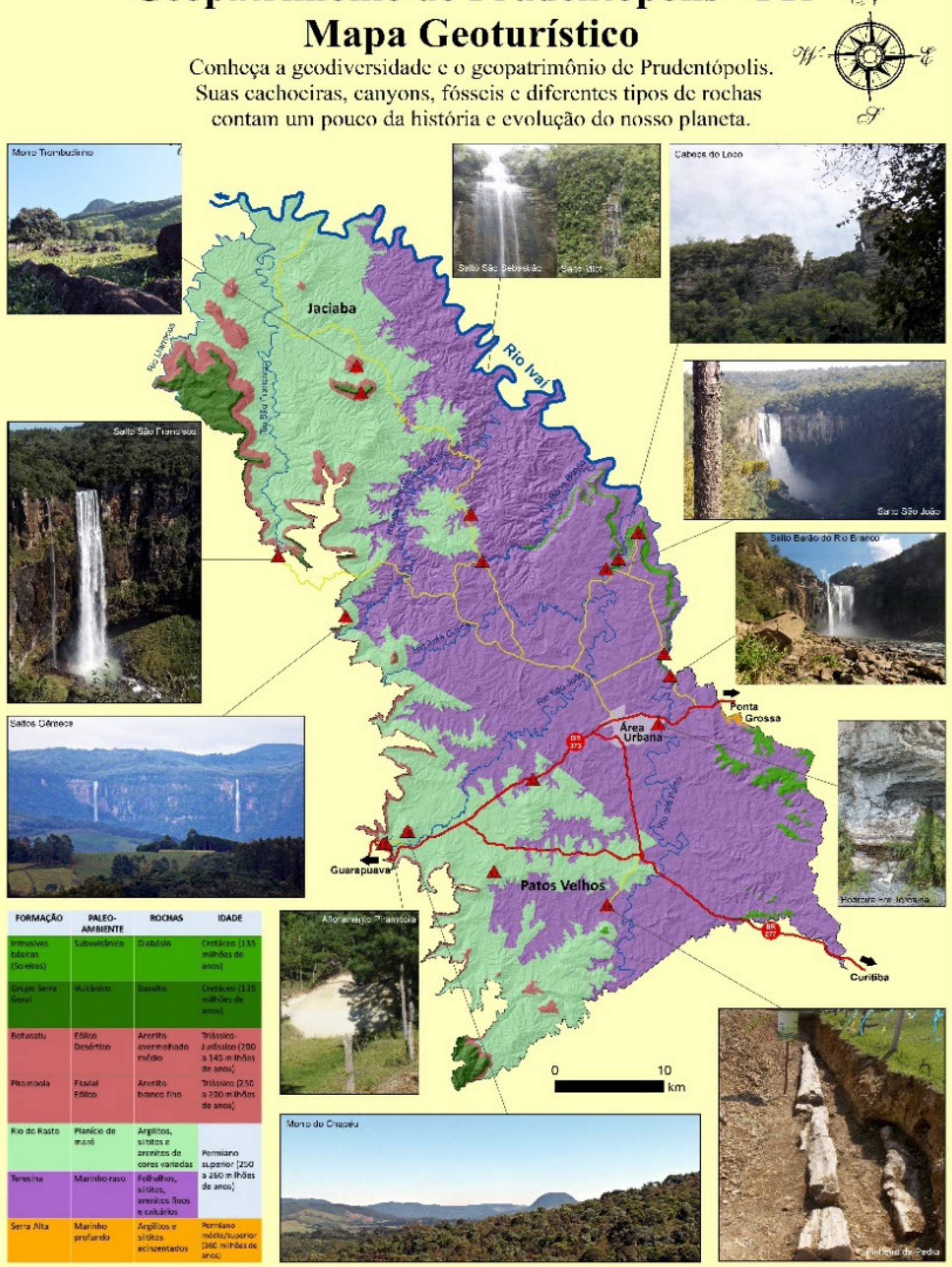
Figura 7 - Verso do Mapa Geoturístico, com informações básicas sobre cada geossítio e o contexto geológico regional.

\begin{tabular}{|c|c|c|c|}
\hline 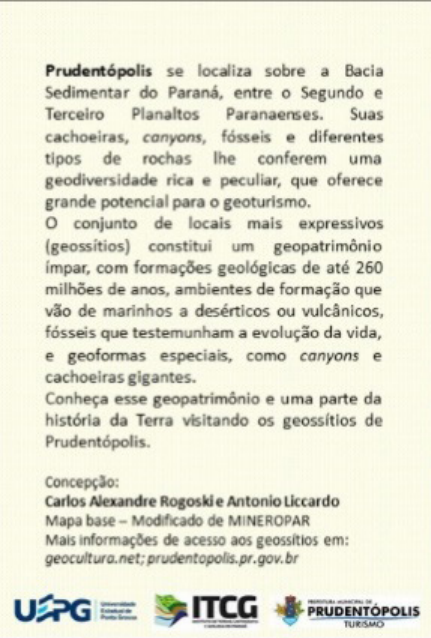 & $\begin{array}{l}\text { Geopatrimônio de } \\
\text { Prudentópolis }\end{array}$ & 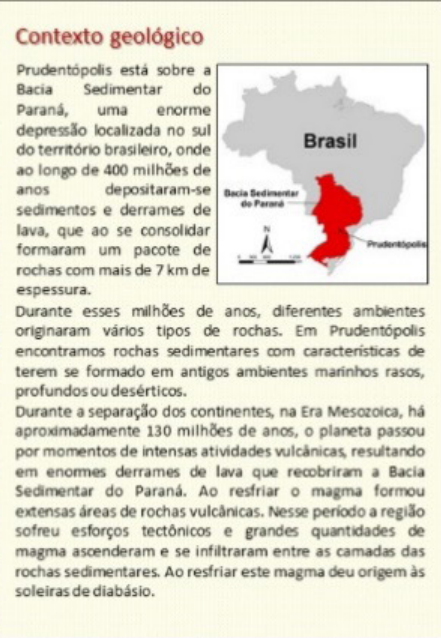 & 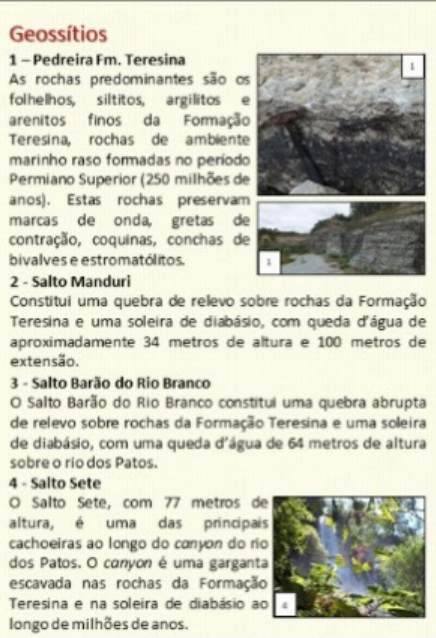 \\
\hline 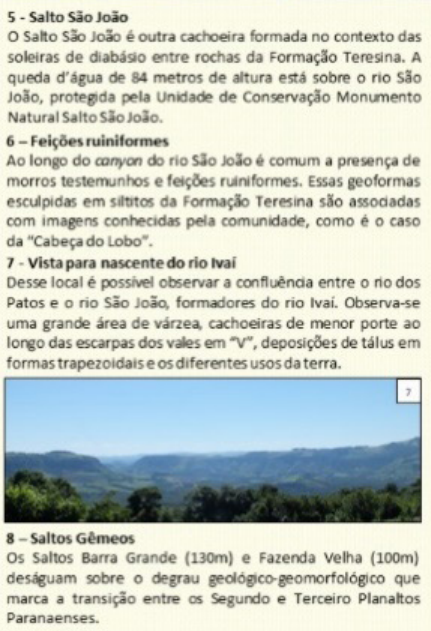 & 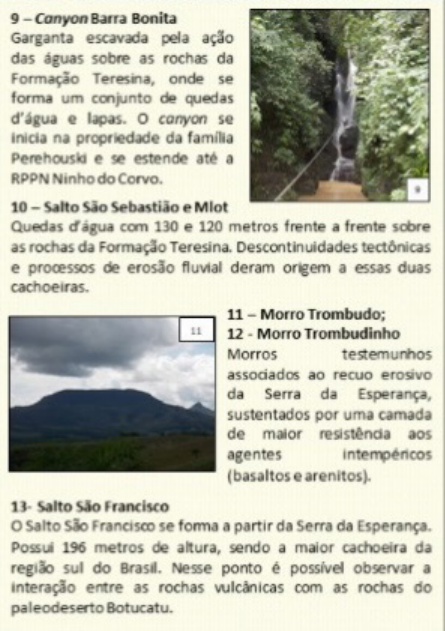 & 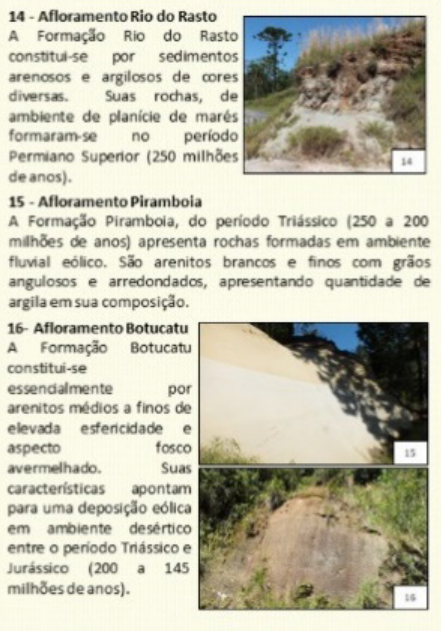 & 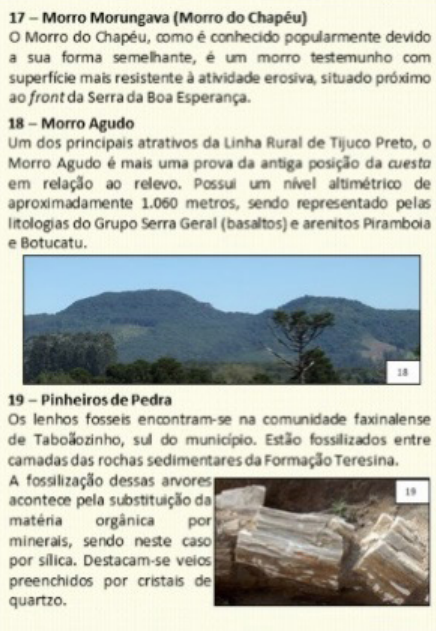 \\
\hline
\end{tabular}

Outro material proposto é um vídeo/documentário educativo sobre a geodiversidade e o geopatrimônio de Prudentópolis. Intitulado "Geopatrimônio de Prudentópolis", o vídeo foi alocado no canal Geodiversidade na Educação do Youtube, (https:/ / www.youtube.com/watch?v=AY3x0QxguYY) e apresenta, de maneira compreensível, informações sobre a geodiversidade e o geopatrimônio do território, com sete minutos de duração.

Espera-se que por meio dos produtos gerados o conhecimento sobre a geodiversidade seja levado até a sociedade em geral, não ficando restrito apenas ao meio acadêmico. São materiais de fácil acesso e desenvolvidos com linguagem facilitada para o público leigo, que, na medida que passem a ser acessados podem despertar um sentimento de afetividade e pertencimento em relação ao patrimônio geológico do território.

\section{CONSIDERAÇÕES FINAIS}

O território de Prudentópolis apresenta uma geodiversidade especial, com rochas originadas em momentos importantes da história da Terra, registros fósseis de alta importância e geoformas singulares. Estes geossítios dão suporte para o entendimento da 
geodiversidade local, do contexto geológico e geomorfológico regional e constituem o geopatrimônio do município.

O levantamento e diagnóstico do geopatrimônio de Prudentópolis expuseram como principais fatores que potencialmente favorecem a prática do geoturismo: 1) a produção de um mapa dos geossítios de relevância científica, didática e cultural; 2) a visitação já existente em grande parte dos locais de interesse com infraestrutura instalada; 3) uma forte interação das comunidades locais com o patrimônio natural e; 4) a facilidade de acesso aos geossítios.

Ao evidenciar os valores científico, didático, estético, cultural, funcional e turístico do geopatrimônio, assim como reconhecer sua representatividade no setor de turismo municipal, aliado ao bom estado de conservação e facilidade de acesso aos geossítios, conclui-se que o município apresenta um relevante potencial para o desenvolvimento efetivo do geoturismo. Sua viabilidade de implantação é, de fato, muito grande, quando consideradas a geodiversidade local e aspectos socioculturais da comunidade prudentopolitana. Para isso é necessária uma ação conjunta entre governantes, comunidade e centros de pesquisa, o que já vem acontecendo por meio de convênio de cooperação entre Prefeitura Municipal de Prudentópolis, Universidade Estadual de Ponta Grossa, Serviço Geológico estadual (ITCG), Secretarias de Estado de Cultura e de Turismo.

A partir desta seleção de geossítios foi publicado um mapa com informações didáticas de cada ponto, o que incentiva a atividade do geoturismo, e permite aos visitantes conhecer o patrimônio geológico de Prudentópolis para além dos aspectos estéticos. Da mesma forma, o vídeo geoeducativo buscou agregar valor aos elementos da geodiversidade e ao geopatrimônio, amplamente disponibilizado, e acessível de qualquer computador ou smartphone, o que pode atingir grande parte da população e potenciais visitantes.

Espera-se que por meio desta estratégia o conhecimento sobre a geodiversidade chegue até a comunidade em geral, não ficando restrito apenas ao meio acadêmico. É almejado também que, na medida em que seja acessado, o geopatrimônio desperte sentimentos de afetividade e pertencimento e que isso fomente a geoconservação em Prudentópolis, que começa a vislumbrar um futuro geoparque.

\section{REFERÊNCIAS}

Brilha J. (2005). Patrimônio Geológico e Geoconservação. A Conservação da Natureza na sua vertente Geológica. São Paulo: Palimage.

Brilha J. (2016). Inventory and Quantitative Assessment of Geosites and Geodiversity Sites: a Review: Geoheritage, 18:119-134

Dowling, R., \& Newsome, D. (2018). Geotourism: definition, characteristics and international perspectives. In R. Dowling, \& D. Newsome. Handbook of Geotourism. Cheltenham: Edward Elgar Pub.

Douhi, N. (2004). Análise das condições físico-ocupacionais e suas implicações no comportamento hídrico da bacia hidrográfica do rio Xaxim - Prudentópolis - PR. (Dissertação de Mestrado em Geografia). Universidade Estadual de Maringá, UEM, Maringá, PR, Brasil. Recuperado de http://www.educadores.diaadia.pr.gov. br/arquivos/File/2010/artigos_teses/teses_geografia2008/dissertacaonelsondoutidohi.pdf

Gray, M. (2004). Geodiversity: valuing and conserving abiotic nature. London: John Wiley and Sons. 
Gray, M. (2013). Geodiversity: valuing and conserving abiotic nature. 2. ed. Chichester: John Wiley and Sons.

Gray, M. (2018). Geodiversity: The backbone of geoheritage and geoconservation. In: E. Reynard, \& J. Brilha. Geoheritage: Assesment, protection, and management. (pp. 13-25). Amsterdam: Elsevier.

Guil, F.G. (2015). As Linhas de Prudentópolis. Curitiba: Arte.

Hose, T.A. (1995). Selling the Story of Britain's Stone. Environmental Interpretation, 10(2):16-17.

Instituto Brasileiro de Geografia e Estatística (1992). Manual técnico da vegetação brasileira. Rio de Janeiro. (Manuais Técnicos de Geociências, 1). Recuperado de http://biblioteca.ibge.gov.br/visualizacao/ monografias/GEBIS\%20-\%20RJ/ManuaisdeGeociencias/Manual\%20Tecnico\%20da \%20Vegetacao \%20 Brasileira\%20n.1.pdf

Instituto Paranaense de Desenvolvimento Econômico e Social (2020). Caderno estatístico município de Prudentópolis. Recuperado de http:/ / www.ipardes.gov.br/cadernos/MontaCadPdf1. php? Municipio $=84400 \& b t O k=0 k$

Instituto de Terras, Cartografia e Geologia do Paraná (2018). Caracterização do meio físico para fins de planejamento urbano com a indicação de riscos geológicos Prudentópolis (PR). Curitiba.

Liccardo, A., \& Guimarães, G.B. (2018). Entrevista com o prof. Dr. José Bernardo Brilha - Universidade do Minho - Portugal. Terr@Plural, 12(3):302-306.

Nascimento, M.A.L., Azevedo, U.R., \& Mantesso-Neto, V. (2008). Geodiversidade, Geoconservação e Geoturismo: trinômio importante para a proteção do patrimônio geológico. São Paulo: SBG-BR.

Neves, J.P., Rohn, R., \& Simões, M.G. (2010). Tafonomia de biválvios em calcários oolíticos da formação Teresina (Bacia do Paraná, Permiano Médio, Prudentópolis, PR). Geologia USP, Série Científica, 10(3):19-36.

Prudentópolis (2015). Prefeitura Municipal. Secretaria Municipal de Turismo. Inventário da oferta turística de Prudentópolis.

Rodrigues, M., \& Fonseca, A. (2008). A Valorização do Geopatrimónio no Desenvolvimento Sustentável de Áreas Rurais. Anais do Colóquio Ibérico de Estudos Rurais - Cultura, Inovação e Território, Coimbra, Portugal, 1. pp. 1-14. Recuperado de http://www.sper.pt/oldsite/actas7cier/PFD/Tema\%20II/2_14.pdf

Rogoski, C.A. (2020). Geopatrimônio de Prudentópolis (PR): valorização e divulgação por meio do geoturismo e educação não formal. Dissertação (Mestrado em Gestão do Território). Universidade Estadual de Ponta Grossa, UEPG, Ponta Grossa, PR. Recuperado de http:/ / tede2.uepg.br/jspui/handle/prefix/3140

Rogoski, C., \& Smaha, J. (2017). Caracterização da paisagem na confluência dos rios Patos e São João (PR), pelo seu potencial para o geoturismo e a geoconservação. Monografia (Trabalho de Conclusão de Curso de Graduação em Geografia). Universidade Estadual de Ponta Grossa, UEPG, Ponta Grossa, PR.

Ruchkys, U.A. (2007). Patrimônio Geológico e Geoconservação no Quadrilátero Ferrífero - Minas Gerais: potencial para a criação de um Geopark da UNESCO. Tese (Doutorado em Geociências). Universidade Federal de Minas Gerais, UFMG, Belo Horizonte, MG. Recuperado de https://repositorio.ufmg.br/handle/1843/MPBB76LHEJ .

Data de submissão: 09/fev./2020

Data de aceite: $20 /$ jun./2020 